fine parallel to the sculptural remainsfrom the great Amarauati Stupa on the staircase of the Museum. The later and more flamboyant and sophisticated Mahāyāna Buddhism, with its appalling medley of manifestations, avatāras, and metaphysical Buddhas, and the fiendish animalism of the Tantrik development, were duly grouped and arranged in serial order. The whole ritual of Lamaism, the clothing of its priests, and the furniture of its temples, were illustrated by a fine series of objects.

It is a real tragedy and a sad thing to be remembered by those who knew our friend that he should not have had the opportunity of publishing a catalogue or at least a handbook of the collection which he set out so well. It is to be hoped that it will be visited by all interested in the mental history, metaphysics, and material representation of the divinities and demons of India and her mental offspring. All this they will see in this fine galaxy of exhibits, and let us hope that they will remember the kind and courteous gentleman who made it possible for us all to study these treasures. Let us hope, too, that the collection will continue to grow in those directions in which it at present has many gaps. This would be the monument our friend would have loved best.

H. H. Howorth.

\title{
Sir Arthur Naylor Wollaston, K.C.I.E.
}

The death on the 8th February of Sir Arthur Wollaston deprived the Society of one of its oldest subscribers. He joined as far back as 1876, and was for many years a prominent member of the Council, giving ungrudgingly of his time and energy to the promotion of the Society's work. A lasting monument of his zeal is the fund which provides the Triennial Gold Medal and the Public School Gold Medal for Indian History. These medals were founded in 1906 with money collected mainly through his instrumentality; and for years he paid the closest attention to the administration of the JRAS. APRIL 1922. 
scheme, remaining a member of the Medal Committee and one of the examiners for the school essays until his death.

His interest in Oriental studies was the natural outcome of his connexion with the India Office, which he entered in 1859 at the age of 16 . Posted to the Political Department (where he had for his chief Sir John Kaye, the well-known historian), young Wollaston set himself to acquire a knowledge of the Persian language as a useful asset in the discharge of his duties. His studies soon showed him the need of an EnglishPersian dictionary, and in 1873 he undertook the task of compiling one, with the aid of a Persian assistant. The result of their labours appeared in the form of a student's dictionary in 1882, and a much larger one seven years later. For many modern European terms no equivalent existed in Persian, and suitable words had therefore to be invented; and it was a source of pride to Wollaston that several of these were actually adopted in Persia.

Before the appearance of these works the author had published in 1877 a translation of the Anwarr-i-Suhaili, and in 1879 an edition of Sir Lewis Pelly's miracle play of Hasan and Husain. In 1886 he produced, in collaboration with Sir Roper Lethbridge, an abridged and revised version of Thornton's Gazetteer of India. In the same year appeared the unfortunately named Half Hours with Muhammad - a popular account of Muhammadanism and its history; and nineteen years later it was recast as The Sword of Islam. Other works of a slighter character were a little book of Persian stories for children, entitled Tales within Tales (1909), and two volumes in the Wisdom of the East series, viz. The Religion of the Koran (1905) and Sadi's Scroll of Wisdom (1906). The latter was reissued in 1908 with the addition of the Persian text.

Wollaston's linguistic labours were recognized in 1886 by his appointment to the Order of the Indian Empire. He had by this time left the Political for the Revenue, Statistics, and Commerce Department, in which he served for fourteen years as Assistant, twice officiating for long periods as 
Secretary. In July, 1898, he was transferred to fresh duties as Registrar and Superintendent of Records, a post which he held until his retirement in October, 1907, after a service of forty-eight years. In the following January he was promoted to K.C.I.E. Not long after his retirement he had the misfortune to lose the sight of one eye; and thenceforward his energies were confined to the locality of his home at Walmer, where for many years he served as a Justice of the Peace and Vice-Chairman of the Wingham Petty Sessional Division. His popularity in the neighbourhood was well attested by the large gathering at his funeral, which took place on the Saturday following his death. W. F.

\section{Mrs. Haynes Bode}

Mabel Kate Haynes Bode was the younger daughter of Robert William Haynes, the well-known law publisher. From him she inherited her love of literature and scholarship, as well as the beautiful voice and enunciation which all who heard her lecture will remember.

She was educated at Notting Hill High School, and always showed a remarkable gift for languages. Later, at the suggestion of Professor Rhys Davids, to whom so many of us owe gratitude, she devoted herself, under his teaching and guidance, to Pali. Her Ph.D. was taken, "summa cum laude," in 1898 at Berne, where she worked with Professor Miller-Hess. In 1904 she studied Sanskrit at Pisa with Professur C. Formichi, who speaks of her "as one of the cleverest and best women I ever met".

But it was at Paris that she found the great intellectual influence of her life in the teaching of M. Sylvain Lévi, and in the unity of spirit, under his inspiration, of a band of scholars joined in loyalty of work, love of truth, and disinterested comradeship. She always spoke of that time as the happiest in her life. French became, as one of her French friends said, "her other language." In 1909 she became Assistant Lecturer, and from 1911 to 1917 Lecturer, at 